\title{
THE RISE OF PRESIDENTIAL POWER BEFORE WORLD WAR II
}

\author{
James T. Patterson*
}

Scholars in constitutional law and political science have outlined a more or less standard view of the development of the American presidency before World War II. ${ }^{1}$ It goes something like this:

The Founding Fathers were ambivalent about executive power. Potential for constitutional expansion of the presidency was inherently great. Seizing on this potential, early presidents-Washington, Jefferson, Polk, above all Lincoln-broadened the role of the office in foreign affairs. War and the threat of war were major sources of presidential power from the beginning.

Meanwhile, important changes in the American political universe-notably the rise of a mass electorate and the creation in the 1830 s of the "second party system"--transformed the presidency from an administrative to a political office. Andrew Jackson became the first great democratic leader.

Despite these developments, the presidency remained relatively weak during most of the nineteenth century. For several extended periods-1810-1829, 1849-1860, 1868-1898-it was an insignificant institution.

From 1898 to 1920 , however, presidential powers escalated rapidly. Among the major causes for such growth were the need for an executive force to mediate between labor and management, the incapacity of other branches of government to stabilize an industrializing society, and, again, foreign affairs and war. Presidents Theodore Roosevelt and Woodrow Wilson drew on remote precedents to establish the modern, "institutionalized" presidency.

After a brief hiatus during the "Republican era" of the 1920s, two new forces augmented presidential power. First, the Great Depression prompted popular demands for White House leadership. Second, the rise of a new electorate of urbanites, immigrants, and blue collar workers gave to Franklin Roosevelt the mass backing, and thus the prestige, that Jackson had enjoyed one hundred years earlier. And popular prestige, political scientists have argued, is the essence of power, at least when power is defined as the ability to

\footnotetext{
* Professor of History, Brown University.

1. See generally J. Burss, Presidential Government: The Crucible of leadership (1965); E. Corwix, The President: Office and Powers, 1787-1948 (4h rev, ed. 1957); E. Hughes, The Living Presidency: The Resources aNd Dilemmas of the American Presidential Office (1972); L. Koenic, The Chiff Executive (1964); H. Laski, The Amfrican Presidency: An Interpretation (1940); C. Rossiter, The American Presidexcy (1956).
} 
get people to do things they otherwise might not have done. ${ }^{2}$ As Harold Laski put it in 1939, American Presidents who secured the support of the people "aroused the dynamic of democracy, an energy, when it is aroused, more powerful and more pervasive than the dynamic of any other form of state." 3

Laski, of course, lamented that the presidency was not stronger than it was. Yet he realized that constitutional vagueness, precedent, war, and socioeconomic pressures had steadily expanded executive power. Like many political scientists, then and since, he thought the presidency to be America's strongest weapon against the banes of social progress: sectionalism, decentralized parties, corporate power, and totalitarianism abroad.

It is hard to quarrel seriously with this general view of the rise of presidential power in America. I will not reiterate it at great length here. But I will recapitulate it briefly, offering qualifications where appropriate. I will also focus on two areas given relatively little attention in those standard accounts which tend to focus narrowly on constitutional development: the growth of popular expectations about the presidency and the relationship between electoral trends and executive power.

Nothing gave the founding fathers more difficulty than the problem of executive power. Many leaders, remembering the excesses of the Crown, called for legislative supremacy. Edmund Randolph argued that a single head of state would become "the foetus of monarchy." Patrick Henry complained that the Constitution was a "squint toward monarchy." Other leaders, however, wished to strengthen the existing system. "Shall we have a King?" John Jay asked after Shays' rebellion in 1787. Perplexed, the framers settled for the cryptic phrase: "The executive power shall be vested in a President of the United States." The Constitution added that the President should be Commander in Chief of the armed forces; that he could issue pardons and reprieves; that, with the concurrence of two-thirds of the Senate, he could "make" treaties; that he could nominate important officials; that he would administer the laws; and that he would "receive ambassadors and other public ministers."

In part because of constitutional vagueness, in part because of the newness

2. See generally R. Neustadt, Presidential Power (1960); Sperlich, Bargaining and Ouerload: An Essay on Presidential Power, in The Presidencr (A. Wildavsky ed. 1969).

3. H. LASk1, supra note 1 , at 268. Rossiter added, "any major reduction now in the powers of the President would leave us naked to our enemies. to the invisible forces of boom and bust at home and to the visible forces of unresi and aggression abroad..." Id. at 159. And Burns concluded. "presidential government. far from being a threat to American democracy. has become the major single institution sustaining it-a bulwark of individual liberty, an agency of popular representation, and a magnet for political action and leadership . . ." Id. at 346 .

4. M. Cunliffe, American Presidents and the Presidexcy 20 (1969)

5. U. S. CoNst. art II, $\$ \$ 1,2,3$. 
of political institutions, the early presidents were relatively weak in three respects. First, they felt obliged to refrain from using the veto power except on constitutional grounds. Washington vetoed only two bills, Adams and Jefferson none, Madison six. (Presidents between 1817 and 1936 issued 742 vetoes. $)^{6}$ Second, they operated on a small scale: In 1800 , when the government moved to Washington, seven packing cases sufficed to move the entire archives of the executive departments. Third, Presidents Washington and Adams did not see themselves as party leaders. Though they awarded contracts in ways aimed at developing local support, and though they sought to counteract the opposition press, they did not try hard to build up a party apparatus, to intervene in local elections, or to manage the news. ${ }^{7}$ Modern presidential leadership involves five major roles or constituencies: contending with Congress, managing the institutionalized office of the executive branch, heading the party, dealing with interest groups, and directing foreign policy. In the 1790 s the first three roles remained in very early stages of development; and the fourth, controlling interest groups, seemed largely irrelevant. The impact of the presidency at home was slight indeed.

Yet from the beginning Washington took advantage of constitutional powers, both explicit and implied. In so doing he set lasting precedents. Thus he insisted on the right to name and to remove heads of departments. They were to be presidential assistants, not-as in parliamentary systems-rival ministers. Using his powers as Commander in Chief, he dealt firmly with the whiskey rebellion in Pennsylvania. An efficient administrator, he profited from the absence of a large bureaucracy and of well-organized pressure groups. He left an important, if immeasurable, legacy of confidence in the central government. ${ }^{8}$

His chief legacy was in the realm of foreign affairs. As Jay had argued in the Federalist Papers, the executive had inherent advantages in conducting foreign relations: capacity for secrecy and dispatch, superior sources of information, and (compared to Congress, which was only infrequently in session), constant involvement in overseas matters." Washington used these advantages to secure the initiative. During his two terms he employed special presidential agents to conduct diplomacy; he negotiated treaties without prior consultation with Congress; he assumed the authority to issue a Neutrality Proclamation; and he reserved the right to recognize or to snub foreign emissaries." When the House, upset at the Jay Treaty with England, asked for papers relating to it, Washington refused to provide them. The House then passed resolutions stating that it had the power (through appropriations)

6. E. Corwas supra note 1 , at 279 .

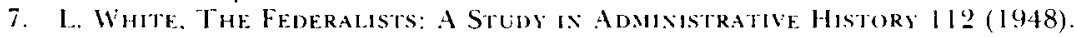

8. II. at $27,37,101$.

9. The Federalis' No. 64 (J. Jav).

10. E. Conwix, supro note 1. at 178-8.3. 
to implement or to hamstring treaties, and that it need not disclose its reasons for asking for information. In so doing it proudly upheld its constitutional authority. In practice, however, Washington had his way. Then, and later, the House shrank from obstructing treaties negotiated by the executive branch and ratified by the Senate. ${ }^{11}$

Jefferson, it seemed, enhanced the role of the presidency. Confronting Chief Justice Marshall, he appeared to argue that executive privilege permitted him to withhold a letter from the court, and to ignore a subpoena that he appear in person to testify. ${ }^{12}$ In the realm of foreign affairs he led the way in securing the Louisiana territory, and he spent unappropriated funds on munitions after England attacked the Chesapeake in 1807. Using his authority as Commander in Chief, he authorized the navy to retaliate against pirates on the Barbary Coast. United States ships, he ordered, should "chastise their [pirates'] insolence-by sinking, burning, or destroying their ships wherever you shall find them." 13

Jefferson was especially innovative as a party and congressional leader. As head of the emerging Republican party, he capitalized on its existence. He supported a party press, promoted partisan supporters in local constituencies, developed congressional liaison, and worked tirelessly with party managers on Capitol Hill. Thanks to his long-time contacts with important legislative leaders, to the absence of well-developed pressure groups, and to Congress' relatively small size, which facilitated tight organization, he dominated the legislature as no subsequent president has been able to do. ${ }^{14}$

Many scholars, however, have shown that Jefferson left the presidency weaker, if anything, than when he took office. ${ }^{15}$ In his dispute with Marshall, he was careful never to claim too much. Thus he conceded that he could be required to testify, and he agreed to deliver the letter to the court. (As it turned out, neither his appearance nor the letter was called for, so the issue was not clearly resolved.) ${ }^{16}$ The President was equally restrained in handling foreign policy. The purchase of Louisiana and the chastisement of pirates were widely popular actions for which he was careful to seek congressional sanction.

Even Jefferson's congressional and party leadership, temporarily so effective, was impossible to emulate. As Congress expanded in size, it became increasingly unmanageable. No president after Jefferson could manipulate it by

11. R. Bercer, Executive Privilege: A Constitutional Myth 171-79 (1974); E. Corwix, supra note $\mathrm{I}$, at 182.

12. R. BERGER, supra note 11 , at 187-91.

13. I The Growth of Presidextial Power: A Documented History 373-74 (W. Goldsmith ed. 1974).

14. See generally J. Youxg, The Washixgton Community: 1800 -1828 (1966),

15. This is the interpretation of Young. Sie also A. Schlesisger, JR., The lmpertal Presidexcy 32 (1973): M. Cunllife. supra note 4. at 68

16. R. Berger, supra note 11 , at 356-61. 
relying on personal meetings and intimate dinners. Indeed Congress was then creating committee structures and institutions, such as "King Caucus," to secure control over nominations of presidents. ${ }^{17}$ In coping with the institutionalization of Congress (and the growth of pressure groups), Jefferson's nineteenth century successors lacked an indispensable resource available to later strong presidents: popular expectations of dynamic executive leadership.

Opponents of President Jackson complained loudly that "King Andrew" was subverting the nation. Henry Clay said, "We are in the midst of a revolution, hitherto bloodless, but tending rapidly towards a total change of the pure republican character of the Government, and to the concentration of all power in the hands of one man." Daniel Webster added, "the President carries on the government; all the rest are subcontractors. . . A Briareus sits in the centre of our system, and with his hundred hands touches everything, controls everything."18

Modern commentators, though refusing to take such partisan rhetoric at face value, have noted changes in the institution of the presidency during Jackson's time. Edward Corwin concluded that "Jackson's presidency was, in truth, no mere revival of the office-it was a remaking of it." 19 Leonard White, author of the most authoritative study of American governmental administration, identified four key developments during the Jacksonian presidency: elaboration of the theory that the president was the direct representative of the people; extension of the veto power to include policy disagreements; unrestrained use of the removal power, leading to creation of a spoils system; and the establishment of presidents as leaders of mass political party organizations. ${ }^{20}$

Evidence of Jackson's assertiveness is readily available. In broadening the removal power, he fired cabinet officers almost at will, and surrounded himself with personal advisors-a "Kitchen Cabinet"-beholden only to himself. ${ }^{21}$ In extending the veto power, he refused to turn over to Congress the draft of the national bank veto that he had read to his cabinet. His refusal made another presidential claim: the right to confidentiality in exchanges with advisers. Challenging the Supreme Court, which had upheld the constitutionality of the bank, he added, "Each public officer who takes an oath to support the Constitution swears that he will support it as he understands it, and not as it is understood by others. . . The opinion of the judges has no more authority over Congress than the opinion of Congress has over the judges, and on that point the President is independent of both."22

\footnotetext{
17. J. Yousc, supra note 14, at 181-210.

18. M. Cunliffe, supra note 4, at 176.

19. Corwin. Some Aspects of the Presidency. 218 Axisals 122. 124 (1941).

20. L. White. The Jacksonians: A Study iN Administrative History 20-49 (195-4). Se' alio

1 The Growth of Presidential Power, sipra note 13, at 330.

21. Ser generally L. White, supra note 20 .

29. 2 a Compilation of the Messages and Papers of the Presidexts. 1789-1897. at 589 (J).
} 
Jackson's chief legacy was his claim, as leader of a new, mass party, to speak for all the people. Like Franklin Roosevelt one hundred years later, he came to office at a time when other social forces-largely anterior to and independent of presidential policies-were moving masses of new voters to the polls for the first time. Claiming to speak on behalf of these new voters, Jackson set himself up as the first popular democratic leader in American history. In so doing he made the presidency a more attractive, and potentially more attainable, prize. Thus it was that such innovations as the national nominating convention, though originating among Jackson's opponents, killed the power of King Caucus. Then, as later in American history, the presidency had unanticipated but far-reaching ramifications on other political institutions. ${ }^{23}$

Still, it is easy to exaggerate Jackson's power. Neither the size nor the structure of the executive branch changed much during his time. Congress did not agree to expansion of the White House staff until 1857, when it authorized a private secretary at $\$ 2500$ a year, a steward at $\$ 1200$, and a messenger at $\$ 900 .{ }^{24}$ Presidents, mired in handling patronage, rarely considered it their duty to develop programs. Jackson, indeed, was less a policy maker than a defender of states' rights, of small government, of old-fashioned republican values. ${ }^{2.5}$ His achievements were largely destructive or preventive. Moreover, increases in presidential activity did not mean that other institutions suffered correspondingly, or that power seeking was a zero-sum game. Congress, more assertive than ever, dominated the government between 1848 and 1860. As Corwin put it, Jackson's " 'dictatorship' " was "more bark than bite, more proclamation than performance." 26

Jackson, in short, was an exception to the general rule of weak presidents in the nineteenth century. He asserted strong claims, only to see them denied to his successors. Such authority as his stemmed from the coincidence, rare in American history, of wo unusual forces: his own strong personality, and the sharp increases in electoral turnout which facilitated the development of mass-based, nonsectional political parties and of popular presidential leadership. By the 1840s, this combination began to break down. The parties fell victim to divisive sectional issues; new, weaker leaders proved unable to take command; Congress reasserted itself; and the presidency suffered accordingly.

Richardson ed. 1896). Sue also A. Schlesicger. Jr. supm note 15. at 45: C. Rossiter. supra note 1 , at 72

93. McCormick. Pollitical Derelopment and the Second Party System, in The AMericax Party Srstems: Stages of Polmical Developaevt 90-116 (W. Chambers \& W. Burnham eds. 1975).

24. L. WhITE. supra note 20 , at $21,72-84,553-67$

25. For conflicting views of the "powers" of patronage see Riker \& Best. Presidential Action in Congressional Nominations. in ThF. Presidexcy, supra note 2, at 250-67; Kelley, Patronage and Presidential Legislatiz's Leadership. in id. at 268-77; for Jacksonian ideology see J. War1, Axdrew JACKSON: SYMBOL FOR AN AGE (1955).

26. E. Cokw1s, supra note 1 , at 311 . 
If political changes provided one source of potential presidential authority in the early nineteenth century, wars and foreign policy provided the other. As early as 1790, Congress gave Washington $\$ 40,000$ to spend as he saw fit on unpublicized diplomatic missions, and in 1811 President Madison received a secret congressional appropriation of $\$ 100,000$ in order to take temporary possession of land south of Georgia. The appropriation was not disclosed until 1818. ${ }^{27}$ In 1817 President Monroe showed what a president could do with the authority as Commander in Chief by sending General Andrew Jackson into Florida to battle the Seminoles. Jackson's imperious behavior nearly provoked war with Spain, which controlled the area. In the same year, Monroe pioneered use of the executive agreement, later a useful way of bypassing congressional consent to treaties. ${ }^{28}$ Six years later Monroe's doctrine concerning Latin America, while binding on no one, was proclaimed in such a way as to make it quasi-official policy of the United States. ${ }^{29}$

James Polk dramatically extended such powers. By stationing troops on disputed territory, he invited hostilities with Mexico. When fighting broke out, he hurried the Congress into recognizing a state of war. In the struggle which followed he demonstrated, in White's words, "the administrative capacities of the presidency as a war agency. He proved that a President could run a war."3" Elaborating on Jackson's concept of popular leadership, Polk explained that " $[t]$ he president represents in the executive department the whole people of the United States, as each member of the legislative department represents portions of them." 31

When Lincoln took office thirteen years later, he might have used such Jacksonian justifications for expanding presidential authority. In fact, he did not. A former Whig, he believed in congressional supremacy over legislative matters, and in a strong cabinet. During his administrations he vetoed only one bill, he left legislative initiative to Congress, and he tolerated broad disagreement from members of his cabinet. ${ }^{32}$

Lincoln relied instead on his powers as Commander in Chief. Justifying his expansive conception of the office, he said in $1864:^{33}$

Was it possible to lose the nation and yet preserve the Constitution? By general law. life and limb must be protected. yet often a limb must be amputated

27. L. Fisher, Presidenthal Spending Power 205, 214 (1975).

28. E. Corwis, supra note 1 , at $212-14$.

29. That is. President Monroe and his successors frequently alluded to the Doctrine in ways that led Americans to regard it as a national policy.

30. L. WhITE. supra note 20, at 50.

31. 4 a Compllation of the Messages and Papers of the Presidents, supra note 22, at 665.

32. D. Donald, Lincoly Reconsidered: Essays on the Civil War Era 187-208 (2d ed. 1965). See also M. CuxlifFe, supra note 4 , at 84.

33. Ser M. Cunliffe, supra note 4, at 84; 10 Complete Works of Abraham Lincoln 65-68 (J. Nicolay \& J. Hay eds. 1894). 
to save a life; but a life is never wisely given to save a limb. I felt that measures otherwise unconstitutional might become lawful by becoming indispensable to the preservation of the Constitution through the preservation of the nation.

So it was that Lincoln used the crisis situation of 1861 to act without congressional sanction. He created a national army out of state militias, maneuvered the country into war over Fort Sumter, called out forty thousand volunteers for three years service, doubled the regular army, blockaded southern ports, and spent two million dollars in funds for unauthorized purposes. Later he suspended the right of habeas corpus and issued an Emancipation Proclamation on his own authority-an announcement as imperious as the czar's emancipation of the serfs. ${ }^{34}$

Lincoln's sweeping assertions of authority revealed the essential inability of Congress to curb or even to oversee a dynamic president bent on acting decisively in times of emergency. His moves, indeed, stunned even those who sympathized with the northern cause. The abolitionist Wendell Phillips called him an "unlimited despot." Lord Bryce said that Lincoln "wielded more authority than any single Englishman has done since Oliver Cromwell." 3.5 The Supreme Court, however, sustained his conception of emergency power, changing its mind only after the war was over. And the voters returned him to office, although by a very narrow margin, in 1864. As Bryce pointed out, the source of Lincoln's unparalleled power was not only the perceived emergency but the democratic base of the American system. ${ }^{36}$ Presidential authority, then as always, depended heavily on power to persuade, and that, in turn, rested on popular consent. Though Lincoln lacked mass backing for his policies, he could count at least on popular acquiescence-and that proved more than enough to sustain his actions.

Lincoln's successor, Andrew Johnson, talked in the Jacksonian vein. "Your President," he said, "is now the Tribune of the people, and, thank God, I am, and I intend to assert the power which the people have placed in me. ${ }^{.35}$ Acting accordingly, he developed his own Reconstruction policies. Though impeached, he stood firm against the Tenure of Office Act, which remained inoperative until its eventual repeal in 1887. His successors in the white House displayed moments of comparable assertiveness. Hayes and Garfield ultimately "won" a protracted struggle with Congress, which had attempted to dictate key appointments, including those of cabinet posts. Hayes vetoed seven House riders to appropriation bills before securing his ends. Confirm-

34. D. DoNALD, supra note 32 , at 187-208.

35. A. Schlesivger, JR., supra note 15, at 59. The Englishman John Bright added in 1861: "There is no greater object of ambition on the political stage on which men are permitted to move" than the presidency of the United States. C. Rossitrar, supro note 1, at 3.

36. A. SChlesinger, Jr., supra note 15 , at 59.

37. H. Beale, The Critical Year 214 (1930). 
ing the presidential veto power on policy issues, Hayes, Arthur, and Cleveland vetoed Chinese immigration acts. By refusing to apply the Sherman Anti-Trust Act against monopolies, Harrison, Cleveland, and Mckinley showed also that presidents could influence policy by the simple expedient of not acting. ${ }^{38}$

Labor turmoil provided a more substantial source of expansion in the presidency. Using an obscure 1807 statute authorizing presidents to employ force "against combinations too powerful to be dealt with in the ordinary course of judicial proceedings," 39 Haves and Cleveland sent in troops to break strikes. The Supreme Court sustained these actions. In 1890 the Court agreed that there was a domestic "peace of the United States," and that the President could keep it. ${ }^{4 "}$ In 1895 it upheld Cleveland's actions against Eugene Debs and the American Railway Union by asserting that the president, even in the absence of statutory authority, could secure injunctions against strikes and dispatch troops to establish order in labor-management relations. ${ }^{41}$ These decisions showed that the ideology of laissez-faire was a front justifying antilabor, pro-corporation activity. They also made presidents into virtual dictators in "emergency" situations on the home front. It was no wonder that the Populists wanted to restrict presidents to one term. ${ }^{42}$

But these expressions of White House authority were rare in the thirty years following 1865. As the struggles against congressional dictation rerealed, the presidency remained on the defensive. A cause of this weakness was the continuing institutional fragility of the office. Though the executive branch expanded during these years (witness the development of agencies such as the Civil Service and Interstate Commerce commissions), the presidency itself remained small. As late as 1900, Congress still authorized the President only one secretary, two assistant secretaries, two executive clerks, and four clerks. ${ }^{43}$ In an age of bureaucratic expansion and rampant economic centralization, the weak institutional base of the White House was a distinct liability to ambitious presidents.

Why did the presidency fail to expand in the post-Civil War years: One reason was the reaction, expressed by the Court in Milligan, ${ }^{4+}$ against the excesses of Lincoln. Congress chimed in by challenging Johnson and his followers. In 1868 it repealed existing laws which had given presidents discretion to

\footnotetext{
38. Issues of these years are covered in L. White. The Republicas Era. 1869-1901: A Stcdi IN Adinistrative History 24-28 (1958): M. Culliffe, supra note 4, at 143.

39. 2 Stat. 443: E. CoRwiN, supra note 1 . at 131-34.

40. In re Neagle, 135 U.S. 1. 2 (1890).

41. In re Debs, 158 U.S. 564 (1895).

42. Roche. Executia' Pouter and Domestic Emergency: The Quest for Prerogatioe. 5 WeSters Pol. (). 592 (1952).

43. J. Buris, supro note 1 , at 55.

44. T1 U.S. (4 Wall) 2 (1866).
} 
transfer appropriations from one department to another, and in 1870 and 1874 it restricted use by presidents of unexpended balances. Congress also refused to ratify any treaties between 1871 and $1898 .^{45}$ As Senator George Hoar later remarked, Congressmen during the Grant years "would have recieved as a personal affront a private message from the White House expressing a desire that they should adopt any course in the discharge of their legislative duties that they did not approve. If they visited the White House, it was to give, not to receive advice." 46 John Sherman, advising President-elect Harrison, said " $[\mathrm{T}]$ he President should have no policy distinct from that of his party, and this is better represented in Congress than in the executive." 47

Broader economic and political forces sustained this long-lived congressional renaissance. Chief among these was the rise of interest groups, especially corporations, which expanded dramatically and dominated the legislative branch. Later, these groups would call on the executive branch for protection against other groups. In the post-Civil War era, however, they were generally content with legislative government and compliant executive leadership. Political forces inhibiting the White House included sectionalism, which divided the parties and prevented any President from claiming to represent all the people; party competitiveness, which resulted in very close elections and in divisions between the executive and legislative branches; and the essential stability of voter turnout. Unlike Jefferson or Wilson before 1919, the post-Civil War Presidents could not count on consistent partisan majorities in Congress. Unlike Jackson or Franklin Roosevelt, they could not claim the support of a massive, "new" electorate.

Given these forces, it was not surprising that contemporary observers of political developments saw little future for the presidency. Professor Woodrow Wilson noted in 1885 that Congress had "entered more and more into the details of administration until it has virtually taken into its own hands all the substantial powers of government." The presidency, he concluded, was "too silent and inactive, too little like a premiership [which Wilson wanted his country to adopt] and too much like a superintendancy." 48 Lord Bryce, after asking rhetorically "why great men are not chosen presidents," explained that ${ }^{49}$

a president need not be a man of brilliant intellectual gifts. . . Eloquence... imagination. profundity of thought or extent of knowledge . . are not necessary for the ordinary discharge in ordinary times of the duties of the post. . . Four-fifths of his work is the same in kind as that which devolves on the chairman of a commercial company or the manager of a railway ....

45. L. Fisher, supra note 27, at 104, 125-26.

46. 2 G. Honr, Autobiography of Seventy Years 46 (1903). See also L. Fisher, supra note 27 , at $104,125-27$

47. H. LASKI, suprn note 1 , at 127.

48. W. Wilson, Congressional Governient: A Study in American Politics 45 (1901).

49. J. Bryce, AmericaN Commonwealth 61 (1896). 
In 1898 the political scientist Henry Jones Ford heralded the rise of the twentieth century presidency. Tracing the growth of executive power under Jackson and his successors, Ford concluded that "in the presidential office . . American democracy has revived the oldest political institution of the race, the elective kingship. It is all there: the precognition of the notables and the tumultuous choice of the freemen, only conformed to modern conditions." "s" Wilson, reversing himself in 1900, agreed. The President, he said, was "now at the front of affairs, as no President, except Lincoln, has been since the first quarter of the nineteenth century. . . U Upon his choice, his character, his experience, hang some of the most weighty issues of the future." 51

In reaching this conclusion both men (especially Wilson) stressed the rise of America to status as a world power. Reflecting currents of opinion which grew in the aftermath of the Spanish-American War, Wilson said that "when foreign affairs play a prominent part in the politics and policy of a nation, its Executive must of necessity be its guide: must utter every initial judgment, take every first step of action, supply the information upon which it is to act, suggest and in large measure control its conduct." ${ }^{52}$ As if to prove Wilson's point, Mckinley took it upon himself in 1900 to send five thousand American troops to China to fight the Boxer rebellion.

Ford and Wilson might have paid more attention to another source of presidential expansion. This was the dramatic change in American politics which followed the depression of the $1890 \mathrm{~s}$ and the polarizing elections of 1894 and 1896. The Republicans, effectively blaming the Democrats for the depression, established a predominantly urban-industrial political base. Unlike the coalitions of Jackson and Franklin Roosevelt, the new GOP did not rest upon masses of new voters who demanded attention. Moreover, the GOP coalition was as much anti-Bryan as anything else; it was surely not "progressive" in any twentieth century definition of that elusive term. But it gave Mckinley a heavily Republican Congress and enabled him to claim a Jacksonian kind of mandate. "I can no longer be called the President of a party," he said. "I am now the President of a people." 53

Mckinley and his successors had still another potential advantage over their forerunners. This was the growth of pressures, which also grew during the depression of the $1890 \mathrm{~s}$, for governmental action to deal with a society changing drastically under the impact of industrialization, urbanization, and mass immigration. At that time such pressure came primarily from potent interest groups, not (as temporarily in the 1930s) from ordinary citizens. It rested in large part on dread of social and political collapse, and on fears that

50. H. Ford, The Rise and Growth of Americas Politics 293 (1898).

51. W. WILson, supra note 48 , at $x$ ii.

52. II.

53. H. Laski, supro note I, at 128. 
other political institutions could not cope with modernization. Reflecting such expectations, the press added to this chorus for "reform"- -and quadrupled its circulation between 1870 and 1920. As the municipalities, the states, and Congress proved inadequately equipped for decisive action, the presidency became a focus of hopes and aspirations.

These rising expectations were often unrealistic, even absurd: The presidency, indeed, was to be a crutch propping up a ragged society. In the long run the increased expectations hurt presidents, who were led to make exaggerated promises and then failed to deliver. Such expectations led also to a faith in charismatic leadership, as if presidential personality could conquer all, and ultimately to the dogma of "our President, right or wrong." Nonetheless, the growth of pressure groups-and the rise in expectations which they developed-became one of the strongest forces in shaping the expanded twentieth century presidency. ${ }^{\text {.4 }}$

Theodore Roosevelt took advantage of all these forces. The President, he felt, was the steward of the people. It was not only his duty but his "legal right to do whatever the needs of the people demand, unless the Constitution or the laws explicitly forbid him to do it." 55 Moving accordingly, he all but seized the Panama Canal. He challenged Congress, which struggled sporadically to contain him, by establishing a protectorate in Santo Domingo, by sending the "Great White Fleet" around the world, and by taking it upon himself to set aside forest reserves. Broadening executive control, he refused to let his attorney general explain to Congress why he had not instituted antitrust proceedings against United States Steel. Instead, Roosevelt ordered the relevant papers to the White House and dared the Senate to come after them. "The only way the Senate or the committee can get those papers," he chortled, "is through my impeachment." 3 " One wonders if Nixon read Theodore Roosevelt's letters.

Theodore Roosevelt proved especially adept at using the new, mass circulation press to bring pressure on Congress. He employed a press secretary, provided reporters with space in the White House, and pioneered in the use of many modern strategems: off-the-record remarks, leaks, and Sunday proclamations for the front pages of Monday morning newspapers. When congressmen balked, as they did during the protracted struggle for the Hepburn Act, he appealed over their heads to the interest groups concerned. Most of all, he and his family were colorful. White House reporters never lacked for

54. See Wildarsky, The Past and Future Presidency, 41 Pub. Interest 56 (Fall 1975). Contemporary writers who expressed high expectations included Wilson. H. Croly, The Promise of American Life (1909); W. LippmaNi, Drift aNd Mastery (1914).

55. T. RoOsevelt, Ax Autobiography 464 (1929).

56. The letters of Archie Butt 305 (L. Abbot ed. 1924). 
copy, or newspaper readers for information about their president. By focusing popular imagination on the presidency Roosevelt whetted pressure group expectations as never before. ${ }^{57}$ Theodore Roosevelt, Walter Lippmann said in 1913, was a "colossal phenomenon," a "working model for a possible American statesman at the beginning of the twentieth century." 58

Though Taft, a strict constitutionalist, tried half-heartedly to limit executive initiative, he fell victim to the very expectations that Theodore Roosevelt had helped to promote. ${ }^{59}$ Wilson, by contrast, had for some time called for a strong presidency. The Chief Executive, he had said in 1907, "is at liberty both in law and in conscience to be as big a man as he can. His capacity will set the limit."6" Expanding on Roosevelt's initiatives, Wilson called twiceweekly press conferences until 1915. He publicized his policies by appearing personally before Congress to announce them, and by going directly to the people for their support. ${ }^{61}$ Perceiving himself as a prime minister, he tried to work carefully with Congress, which was Democratic until 1919. In so doing he had to act pragmatically, often inconsistently. Like Jefferson, he became ultimately dependent on his congressional supporters. ${ }^{62}$ But he also showed that a president could be a strong legislative and party leader. Liberals like Lippmann were heartened by the show of executive purpose.

In his conduct of foreign relations, Wilson acted in more high-handed ways designed to augment presidential initiative. His Mexican policies left Congress little choice but to approve the occupation of Vera Cruz and the expedition against Villa. During World War I he capitalized on what Corwin later called "altogether revolutionary legislation" "63 to set up executive agencies which attempted to oversee mobilization and which engineered far-reaching violations of civil liberties. Two policies of long-range importance-the 14 Points and the Siberian expedition-were developed without any real consultation with Congress. Like Theodore Roosevelt, he offered a model of charismatic leadership, which, though potentially dangerous, seemed to offer much to groups that despaired at the weakness of other political institutions.

57. E. Corninel. Presidestial Leadership of Public Opiniox 14-25 (1965).

58. W. Lipparax, Preface to Politics (1913), quoted in M. Cunliffe, suprn note 4. at 200.

59. For Tafis views se W. Taft, Our Chiff Magistrate and His Powers (1916). He wrote: "[T]he President can exercise no power which cannot be fairly and reasonably traced to some specific grant of power or justly implied and included within such express grant as proper and necessary $t o$ its exercise... There is no undefined residum of power which he can exercise because it seems to him to be in the public interest...."Id. at 139-40.

60. W. Wilson, Constitutional Government in the United States 69 (1907).

61. E. CORNwell, supra note 57 , at 32-59.

62. J. Burxs, supra note 1, at 204. See also the seminal article by Chamberlain, The Presidem. Congress, and Legislation. 6 PoL. Sci. Q. 42 (1946). It debunks the notion that Wilson-and later presidents through Franklin D. Roosevelt-had the primary impact in legislation.

63. E. Conwis, supra note 1 , at 236. 
By focusing on the personalities of Harding, Coolidge, and Hoover, it is easy to perceive an atrophy in presidential authority after 1920. Coolidge, after all, contended, "I have never felt it was my duty to attempt to coerce Senators or Representatives, or to make reprisals. The people sent them to Washington. I felt I had discharged my duty when I had done the best I could with them." ${ }^{4}$ Hoover added, "the militant safeguard to liberty . . [is] legislative independence. . . More particularly does the weakening of the legislative arm lead to encroachment by the executive upon legislative and judicial functions, and inevitably that encroachment is upon individual liberty." "6s

Such rhetoric aside, these presidents did not reject opportunities to advance presidential authority. Like Wilson, Harding was quick to use federal troops for the pacification of labor disputes, while Coolidge followed the lead of both Theodore Roosevelt and Wilson in sending soldiers to the Caribbean without congressional consent. ${ }^{66}$ The GOP presidents also capitalized on the ever-present passion of the media for news about the White House. Harding restored regular press conferences, which had been a casualty of war and of Wilson's illness. He pioneered in use of the device of "White House spokesman." He was the first president to have a "speech writer" on his staff, and regularly to use amplification for public addresses. Coolidge, far from being the "quiet president," held regular press conferences not only to get himself in the news but also to influence legislation and to sustain business confidence. He made more public speeches than Wilson. Hoover, though a failure at press relations while president, had been a brilliant self-promoter while Secretary of Commerce under Harding and Coolidge. ${ }^{67}$ His assiduously cultivated image as the "great engineer" did much to propel him into the presidency and to increase expectations about the virtues of social engineering. In part because of their skillful use of the mass media, Harding and Coolidge (and Hoover until 1930) developed enormous popular support during their tenures. When Harding died, the outpouring of grief was massive and spontaneous.

Two broader, extra-systemic forces sustained the presidency during these years. One was the legacy of charismatic leadership left by Theodore Roosevelt and Wilson. Propounded as an answer to the nation's problems before the war, executive forcefulness became almost an article of faith among

64. C. Coolidge, Autobiography of Calvis Coolidge 232 (1929).

65. H. Hoover. Challenge to Liberty 125-26 (1934).

66. Rossiter, The President and Labor Disputes, 1 I J. Politics 93 (1949).

67. E. Corvwell. supra note 57, at 61-108. See generally C. Llovd. Aggressive INTrovert: A Siudy of Herbert Hoover axd Public Relations Managemext. 1912-1932 (1972): J. Wilsox, Herbert Hoover: Forgottex Progressive 79-121 (1975). 
many political scientists and progressives during and after World War 1 . Wilson's struggle for the League of Nations merely intensified this faith. Instead of interpreting his defeat as a manifestation of popular disenchantment with spread-eagle rhetoric, progressives blamed a cabal of senatorial isolationists and partisans, denounced the legislative branch, and clamored loudly for a renaissance of presidential power. When Franklin Roosevelt expanded the office after 1932, he worked in a political culture whose liberal spokesmen already identified "reform" with "presidential leadership."

Political scientists joined economists and other "experts" in promoting the second broad force toward presidential expansion in the 1920s: the passion for organization, rational planning, and efficiency. This passion, of course, was neither new to the 1920 s nor applicable only to government. Moreover, in the 1920s the drive for efficiency often meant cost-cutting and small government, especially on the state level. ${ }^{i 8}$ In a general way, however, the drive for rational planning in the 1920 s stemmed from dissatisfaction by elites with the "people" and with the corruption and wastefulness of legislative bodies. Given the essential "stupidity" of the people and of popularly elected representatives, it followed that experts in the executive branch must devise and administer programs. On the local level this attitude sustained the movement for city manager and commission forms of government, which peaked in the 1920s. On the national level it meant the growth of organized social science to package socio-economic policy. The Budget Act of 1921, which made it the role of the executive branch to propose annual budgets, was merely the most dramatic sign of the trend toward social engineering. ${ }^{69}$ Hoover's research committees on social and economic trends, and the Reorganization Act of 1939 establishing an executive office, were later manifestations. In advancing this tradition-and utilizing exponents of it such as Rexford Tugwell and Adolf Berle-Roosevelt was on familiar territory. The presidency, America's "great engine of democracy," was becoming an alternative to "misrule" by the Congress or subservience to the "interests."

\section{IV}

Franklin Roosevelt's contributions to an expanded presidency are wellknown. Receiving unprecedented power, he established a host of new agen-

68. For historical interpretations stressing these factors see BUILDING THE ORGaNizational Society: Essays of Associational Activities in Modern America (J. lsrael ed. 1972); G. Tindall. The Emergence of the New South, 1913-1945, at 219-53 (1967); R. Wiebe, The Search for Order, 1877-1920 (1967); Hays, The Social Analysis of American Political History, 80 Pol. Sci. Q. 323 (1965).

69. See gemerally B. Karl. Charles E. Mreriam and the Study of Politics (1974); G. Lyons. The Uneasy Partiership: Social Science and the federal Governmest in the Twentieth Century (1969): E. Purcelle, JR., The Crisis of Democratic Theory: Scientific Naturalism ANd THE Problem of Value (1973); Eakins, The Origins of Corporate Liberal Policy Research, 1916-1922: The Political Economic Expert and the Decline of Public Debate, in Buildixg THE Organizational Societr, supra note 68 , at 163. 
cies. Congress gave him $\$ 15.4$ billion in discretionary funds during his first term (previous presidents had received only $\$ 1.6$ billion). Despite his fiscal conservatism, he tripled federal spending, much of it distributed by executive aides like relief director Harry Hopkins. He issued 2538 executive orders between 1933 and 1939, compared to Theodore Roosevelt's 1011, Wilson's 1770, and Hoover's 1004..$^{71}$ Perhaps the most striking example of his appeal was the impact of his presidency on White House activities. Ira Smith, head of the President's mail service for fifty years, noted that during peak periods, as at the time of the coal strike of 1902, one thousand pieces of correspondence a day had arrived at the White House. Franklin Roosevelt's inauguration, by contrast, evoked 460,000 letters. Under Hoover, Smith had handled the mail room by himself. Under Franklin Roosevelt he required a staff of fifty, plus two additional rooms. The average during Roosevelt's twelve years was five thousand pieces of mail per day. ${ }^{71}$

The sources of Roosevelt's strength until 1937 resembled those of other strong Presidents. Like McKinley and Theodore Roosevelt, he had little to fear from the opposition party, which was badly demoralized. Like Jackson, he drew popular support from a rising coalition of new voters-generally the immigrants, blacks, blue collar workers, and poor people of the 1930s. Like Wilson, he enjoyed partisan backing in Congress. Above all, he came to power after four years of depression, which American political institutions seemed incapable of ending. In desperation, ordinary citizens now echoed the demands of social engineers in crying out for action from the central government. Remembering Theodore Roosevelt and Wilson, they looked first to the presidency for charismatic leadership. The major forces assisting a strong presidency in the past-a new political universe, an emergency situation, the apparent paralysis of other institutions, a yearning for leadership-combined at once in 1933 to give Franklin Roosevelt unparalleled opportunities for broadening his reach. And as the fascist menace developed in the late $1930 \mathrm{~s}$, the threat of war-historically the strongest force of all behind presidential aggrandizement-gave the President yet one more, ultimately unassailable, reason to provide energetic leadership. ${ }^{i 2}$

Given Roosevelt's activism, it was not surprising that conservative critics worried in 1939-1940 about the future of American democracy. As he prepared to run for a third term, his opponents coined slogans: "No Crown for Franklin," "No Third Term-ites," "OUT! Stealing Third." Lawrence Sullivan

70. C. Patterson, Presidential, Governaent ix the united States: The Unwrittex Constitution 146 (1947): L. Fisher, supra note 27, at 62-63.

71. L. Brownlow. The Presidext axd the Presidency 62-72 (1949).

72. The Supreme Court, in United State's 2 . Curtiss-Wright Expont Corp. . reaffirmed presidential power in the area of foreign affairs. "In this vast external realm, with its important. complicated. delicate, and manifold problems. the President alone has the power to speak or listen as a representative of the nation." 299 U.S. 304,319 (1936). 
complained that "we are tending at the moment toward a form of one-man government administered through myriad bureaus whose administrators write the laws, interpret them in application, and punish violations with their own decrees and penalties." ${ }^{73}$ A more scholarly critic, Edward Corwin, wrote in 1941 that "the President dominates Congress by the hold which fat relief rolls give him over millions of voters, and so a vicious circle is created whereby Congress pays for its own slow enslavement." He added that "propaganda, once the casual art of a gifted few, has been converted into a skilled technique, which is supplemented by the most ingenious gadgets of mechanical science." ${ }^{74}$

In the long run, some of Corwin's fears proved well-founded. At the time, however, many political scientists complained that Roosevelt was not strong enough, that he was more of an incrementalist and an opportunist than a powerful leader. Even during his first term he was neither so dominant nor Congress so compliant as many observers seemed to think. ${ }^{75}$ In his second term he enjoyed massive Democratic majorities, yet failed to pack the Supreme Court or to secure important domestic legislation. In 1938 he was unable to purge dissidents from Congress, and in 1939 he had to fight hard to get a limited reorganization act. Stymied, he made no real effort-this was left to Truman-to offer prepackaged programs at the start of congressional sessions. ${ }^{76}$

Roosevelt's frustrations in domestic matters suggested several relevant facts about the presidency before 1940. First, power did not exist as in a zero-sum game: while the presidents extended their reach, so did Congress and the federal bureaucracy. Second, interest groups might call for vigorous presidential leadership_-and thereby enhance expectations-but they showed little desire to help the White House secure legislation which did not directly benefit them. Third, presidential popularity at election time did not-does notnecessarily lead to a rise in presidential power. After 1937 Roosevelt and his successors were rarely able to transform electoral strength into clout on Capitol Hill. For all these reasons the gap between actual presidential power-measured as the capacity to get people to do things they otherwise might not have done-and expectations of power, was wide indeed.

Hemmed in as he was on the domestic front, Roosevelt might logically have used foreign affairs as a means of enhancing his authority. Wars and

73. L. Sullivax, The Dead Haxd of Burfalcracy 15,16 (1940).

74. Corwin, supm note 19, at 128-29. Another cautious view at the time was expressed by E.P. Herking, Presidential. Leadership (1940).

75. See Chamberlain. supra note 62. for a persuasive interpretation along these lines.

76. See J. Burxs. Koosevelt: The Liox and THE Fox 291-406 (1956); Goostre. The Pozer of the President to Impound Appropriated Funds, 11 AM. U.L. Rev. 32 (1962); Neustadt, Presidency and Legislation: Plaming the President's Program. 49 Ax. Pol. Sca. Rev. 980 (1955); Wildavsky, The Ta'o Presidencies, 4 Trass-actos 7 (Dec. 1966). 
threats of war, after all, had been primary causes of expansion in presidential power. In 1940-1941 he did move in that direction. At that time he ordered wire-tapping to be used on "suspected spies" and on people "suspected of subversive activities" damaging to the nation's foreign policy ${ }^{77}$ Like his predecessors in times of need, he impounded funds on a small scale. He took steps of highly questionable legality, like the destroyer deal, to secure his aims. Even so, he acted with restraint, in part because Congress was unusually watchful and suspicious. Roosevelt's relative openness and political caution, indeed, contrasted sharply with the later high-handedness of Johnson and Nixon. In 1941 the foreign affairs presidency was far from the potent force it was to become in the postwar years.

Still, the rapidity with which Franklin Roosevelt and his successors extended their power after 1940 suggests the potency, as of that time, of forces assisting ambitious Presidents. The labor unions, a growing new force in electoral politics, were now disposed to support strong executive leadership. ${ }^{78}$ Their presence among the plethora of interest groups created added pressures on Presidents to act decisively. Moreover, many liberal social scientists and intellectuals continued to place their faith in the Theodore Roosevelt-Wilsonian model of leadership. As in earlier years, these "experts" were contemptuous of Congress, worried about the "interests," and were persuaded that the nation needed political centralization. The 1930s witnessed the fateful convergence of expectations-by voters, interest groups, and liberal social scientists-in presidential potential.

No one typified such views more clearly than the English political scientist, Harold Laski, whose book on the American presidency appeared in 1939. ${ }^{79}$ Laski called eloquently for the strengthening of the presidency, the best weapon against sectionalism, corporate interest groups, and decentralized political parties. "America," he said, "needs strong government; it needs strong leadership to attain strong government; only the President, granted its characteristics, can provide it with the leadership it requires." Such leadership was especially essential in foreign policy. "The citizen," Laski wrote, "looks to his [the President's] pronouncements with exceptional anxiety. He has the sense, as never before, that America is a world power, and that his President must play his part in a manner proportionate to the influence of the United States in world affairs." 80

Laski, a socialist, hardly typified American opinion on the eve of World War 11. Nonetheless, his writings reflected the pronounced bias of many political scientists for powerful executive leadership. Anticipating Richard

77. Theoharis, Thirty Years of Wire Tapping. 212 NATION 744 (1971).

78. J. BurNs, supra note 1, at 101-03.

79. H. LASKi, supra note 1.

80. Id. at $182,244$. 
Neustadt, ${ }^{81}$ he stressed the key connections between presidential popularity, prestige, ability to persuade, and power. Later advocates of a strong presidency elaborated on his ideas, but did not disagree with the basic perspective. Like Laski, like many anxious Americans in the age of depression and world war, they saw no better way of bringing order to a frayed society, of compensating for decentralized political parties and the federal system, or of combatting fascism and communism. Given such expectations for activist leadership-and the gap which separated these expectations from constitutional authority-it was not surprising that Presidents after 1940 looked for ways to maximize their influence, even if it meant riding roughshod over constitutional guarantees and civil liberties.

81. Ser gemerally R. NeustadT. supra note 2. 